\title{
NIETZSCHE E A ESTILIZAÇÃO DE UM CARÁTER
}

- RESUMO: O artigo aborda o tema da estilização do caráter no pensamento de Friedrich Nietzsche, através da apropriação de alguns dos temas centrais da sua filosofia, tais como a crítica avaliativa da modernidade ocidental, o pensamento do 'eterno retorno' e o sentido da 'extemporaneidade' [unzeitgemässe]. Através de um percurso pelo conjunto da sua obra e pelos textos de alguns dos seus comentadores, procura-se estabelecer uma interpretação do significado da sabedoria ativa através do desenvolvimento e embaralhamento, ao mesmo tempo livre e cuidadoso, dos temas referidos acima

- PALAVRAS-CHAVE: Nietzsche; estilização do caráter; eterno retorno; extemporaneidade; solidão.

\section{Um espírito em tensão com seu tempo}

Nietzsche refere-se a um dos seus livros (Jenseits von Gut und Böse [Além do bem e do mal]) como uma "crítica da modernidade", acompanhada de "indicações para um tipo antitético que é o menos moderno possível, um tipo nobre, que diz Sim" (Nietzsche, 1995, p.95). Com essa e outras palavras, ele assevera que a modernidade lhe era uma referência de posicionamento, todavia, jamais como destino, fim ou saúde, mas sim como meio e doença, em que ele sempre julgou ter de aprofundar-se e, mesmo, arriscar-se para o seu propósito maior de superar a humanidade no indivíduo.

1 Professor Adjunto do Departamento de Sociologia e Antropologia e do Programa de Pós-Graduação em Sociologia da Universidade Federal de Minas Gerais-UFMG. Artigo recebido em set/06 e aprovado para publicação em nov/06. 
As críticas de Nietzsche à cultura ocidental terão, talvez pela primeira vez na história da filosofia, uma significação absoluta, que transcende a própria idéia do posicionamento como mera crítica. Na medida em que as suas críticas perpassaram vários âmbitos das formações de valor, em busca dos fundamentos afetivos mais profundos e de suas associações disfarçadas, elas conduziram a uma conclusão de radicalidade nunca antes vista: uma crítica ao homem e às coisas humanas como referência de valor, no sentido de uma avaliação destrutiva dos velhos (religiosos) e novos (seculares) valores. Assim, dos grandes filósofos modernos, Nietzsche foi o mais decididamente anti-humanista, não só pela extensão e sentido das críticas mas também por se negar a extrair delas algum indicador de correção, melhoramento ou consolo para a humanidade.

O anti-humanismo de Nietzsche - no sentido que aqui será abordado é decorrência da direção que ele deu aos seus pensamentos, fazendo deles um campo de batalha contra as tendências do "seu tempo", o que ele denominou seu projeto de "transvaloração de todos os valores" e sua natureza "extemporânea". Prova disso é que, em uma espécie de paradoxo irônico, quando o filósofo diz estar entre "os mais modernos dos modernos" significava "que amamos tanto mais a natureza quanto menos humana ela se mostra, e a arte, quando é refúgio [Flucht] do artista ante o ser humano e escárnio do artista ao ser humano ou a si mesmo" (Nietzsche, 2000, §379). Ele visou à transvaloração e não à vitalização da civilização ou ao retorno à natureza. No primeiro caso, tratar-se-ia de aprofundar a experiência moderna através da correção de erros, dogmas e práticas, mas afirmando as suas mais "recentes" novas forças, como exemplificado com a crença na razão edificante de saberes e mesmo de posturas morais; no segundo caso, tratar-se-ia da valoração do sensualismo, do naturalismo e dos bons sentimentos como apanágio contra a frieza e o superficialismo da vida moderna, como no romantismo. ${ }^{2}$ Kant, em um caso, Rousseau, Schopenhauer e Wagner, no outro.

Certamente Nietzsche, para escapar do romantismo, foi influenciado pelo ceticismo filosófico e científico, o qual lhe prescreveu em boa medida o pessimismo. Mas ele não aderiu incondicionalmente ao ceticismo, sobretudo quando este demostrava demasiada "seriedade" ou, mais tardiamente, uma ânsia de neutralidade. O problema do cético moderno é que ele, ao enredar-se na dúvida, quer ser neutro a ponto de não conseguir mais estabelecer hierarquias de valor, caindo na inação e no relativismo, tendo Nietzs-

2 Will Durant faz uma leitura exagerada de Nietzsche como um tipo romântico, chegando a dizer que o filósofo "foi, para a filosofia da sua época, (...) a culminância do movimento romântico (...) o último grande rebento da linguagem de Rousseau" (1991, p.404), quando o naturalismo imoral de Nietzsche é absolutamente antipático ao naturalismo do bom selvagem rousseauniano (Nietzsche, 2000a, § 463). 
che avaliado o ceticismo extremado, cientificista, como sintoma de uma doença, que "dispõe dos mais belos trajes; e a maior parte, por exemplo, daquilo que hoje se expõe nas vitrinas como 'objetividade', 'cientificidade', 'l'art pour l'art', 'conhecimento puro, livre da vontade', é apenas ceticismo ornamentado e paralisia da vontade". (Nietzsche, 1988, §208) Para Nietzsche, a impessoalidade, a igualdade, a universalidade e a tolerância tão propaladas na modernidade simbolizam, ao mesmo tempo em que efetivam, "a supressão do sentimento de distância, essencial à avaliação nobre: para esta, toda exigência é particular; ela se exerce inter pares, como um direito exclusivo" (Kossovitch, 1979, p.87). Os efeitos dos sentimentos e valores modernos acima são a massificação e a repetição.

"Quais são, afinal, as verdade do homem?" O "cético derradeiro" responde: "São os erros irrefutáveis do homem" (Nietzsche, 2000, §265); mas quem ainda acredita em refutações tende a crer em verdades. Nietzsche não queria refutar, mas manipular com senso de distância: "Eu não refuto os ideais, apenas calço luvas diante deles." Nietzsche não repudiou a ciência como saber, no que ela se mostrava criativa, mas como conhecimento do verdadeiro (leis, causas), como princípio de igualação (busca do regular e do genérico) e como ideal de imparcialidade. Assim, o ceticismo é útil como meio e arma, fonte de dureza, e não como fim ou pathos. Já o problema do romântico pessimista é que ele é um tipo que busca ora "quietude" e "redenção" ora "embriaguez" e "loucura". Mesmo sendo profundo em sua visão do mal, da dor e do sofrimento, ele é incapaz do ato mal e terrível ou de não clamar por consolo para a alma; e mesmo sendo autêntico e pessoal, é incapaz de expressar gratidão e alegria de modo profundo, revelando na sua criação "a imagem da 'sua' tortura" (idem, §370). Cansado de tanto procurar por consolo, tende a declarar a ausência de sentido e as vantagens da quietude da vontade. Por isso, romantismo, ceticismo, ascetismo: todas essas perspectivas são dominadas pela gravidade do "nada".

Os tipos modernos do cético e do romântico são as grandes antíteses de todas as designações às quais Nietzsche associou o projeto de transvaloração: o "além do homem", o "espírito livre", o "artista dionisíaco", o "imoralista" etc.; com elas, ele buscava precisamente expressar o ideal de um espírito que cria valores, porque tem dignidade e nobreza para tanto, e de um espírito que seja capaz de transbordar em alegria, de rir do saber trágico e da própria dor. Os limites do romantismo e do ceticismo são, respectivamente, a falta de dureza, para avaliar, e a seriedade e a falta de estilo, para rir e criar. Sabe-se que Nietzsche sentiu-se tentado pelos dois campos; mais do que isso, por vezes lançou sobre eles muitas das suas esperanças e disposições, como filósofo-artista e como filósofo-cientista, o que de modo especial talvez possa ser atestado nas obras $\mathrm{O}$ nascimento da tragédia e $\mathrm{Hu}$ mano, demasiado humano. Entretanto, buscou fazer suas rupturas com tais 
legados e trilhar a "sétima solidão" em busca do seu estilo, pois "uma coisa é necessária - 'dar estilo' a seu caráter - uma arte grande e rara! É praticada por aquele que vê tudo que sua natureza oferece de forças e fraquezas, e as ajusta a um plano artístico, até que cada uma apareça como arte e razão e também que a fraqueza ainda encante o olhar" (idem, §290). O criador dionisíaco é aquele que sabe dosar dureza e leveza; algo como "hay que endurecerse, pero sin perder la leveza jamás!". O decisivo era o caráter, impresso pela hierarquia de cada organização de força, o qual não pode ser inventado, apenas moldado, dobrado, transfigurado. "Ouem na juventude não tem um coração duro, jamais o terá" (Nietzsche, 1988, §260). Um caráter forte é feito de uma boa hierarquia de comandos, como que um único "gosto" a comandar o grande e o pequeno. E o "personalismo" de Nietzsche não pode ser tomado como um egoísmo ou hedonismo vulgares, mas - como artista, que mais ama a obra do que a si - é uma forma de valoração "objetiva", enquanto afirmação de um caráter para além dos caprichos e das veleidades da alma (Simmel, 1950, p.189).

A distinção entre espírito e humanidade é fundamental para a compreensão do pathos nietzschiano e seu sentido de superação do moderno. Ela tem a ver com a idéia de que o espírito deve movimentar-se em direção à natureza, às forças vitais, opor-se ao cultivo da consciência e dos valores civilizados como fim maior. É o estilizar-se em direção ao seu "caráter" (Nietzsche, 2000, §290). Ao indagar sobre "quando é que todas essas sombras de Deus não nos obscurecerão mais a vista? Quando teremos desdivinizado completamente a natureza? Quando poderemos começar a naturalizar os seres humanos com uma pura natureza, de nova maneira descoberta e redimida?" (idem, §109), vê-se, nesse intuito de "naturalização" do homem, o caráter antimoderno do qual o filósofo se sentia constituído, o que não deve ser confundido com um retorno à natureza, mas como movimento de elevação, ou "cultivação" da sua "segunda natureza", ou, em relação ao conjunto das tradições culturais, "transvaloração de todos os valores". Contra Rousseau, achava que à natureza não se deve "regressar", mas, inversamente, "alcançar".

O fundamental é que a vivência da transvaloração é a própria capacidade de criação de novos valores isentos de "amoralina", a explicitação de novas formações de forças que nada mais carreguem de má consciência, de compaixão, de ressentimento, de fé inabalável em alguma meta, de esperança de salvação ou melhora, de vontade de ser a humanidade boa ou feliz; o ato criador é o único mecanismo de efetiva superação da dependência do outro e da consciência culposa dela originada (Costa, 2001, p.69). Os novos valores não são novos "ideais", mas "produções artísticas", ou a sensação íntegra de ter os pensamentos como "estilizações" dos afetos e a própria vida espiritualizada como obra de arte. A transvaloração é essencialmente afirmativa. O trabalho artístico de estilização comanda a "saúde", dirige o jogo 
destruição/criação entre os espíritos mais elevados. As produções artísticas como produto de complexos de forças bem hierarquizadas, em que há abundância e fluência de potências. A arte como tônus de elevação espiritual.

Em relação à sua natureza, o desafio do homem "senhor de si" não está no controle ou na liberação dos instintos, mas no modo como ele os interpreta, vale dizer, os estiliza. Um espírito que é livre a ponto de enobrecer o seu caráter demonstra, com isso, rara habilidade de "tornar-se o que é". Para Nietzsche, somente um espírito cujo caráter corresponde à abundância de forças é capaz de se elevar a uma "segunda natureza" e "tornar-se o que é"; a "segunda natureza" como grande obra interpretativa dos espíritos abundantes. Todo espírito "é", no sentido de que tem uma natureza fisiopsicológica; mas o "tornar-se o que é" constitui a ação interpretativa que reúne afetos de comando necessários para essa "elevação". E, por possuir suas fraquezas, desvanecimentos e perecimentos como qualquer outro complexo espiritualizado de forças, somente por "atos interpretativos" é que um espírito forte pode refletir em si a elaboração do que possui de elevado e fraco, conferindo lhes "razão" e "sentido artístico" (Nietzsche, 2000, §290).

Nietzsche acreditava haver "espiritualidade" no corpo, nos sentimentos e na linguagem, e que tais registros encontravam-se, eles próprios, imbricados uns nos outros, ou noutros termos, uma "espiritualidade" é uma quimera de química, de sentimentos e de representações - e quantos elementos mais? Por isso, o filósofo jogou por terra o que considerava as ilusões da naturalização (romantismo), da racionalização (hegelianismo), da conscientização (socratismo) e da salvação (cristianismo) do espírito. O espírito não vem do corpo nem é vivido na alma ou muito menos na consciência; ele é um amálgama móvel de tudo isso. Não se trata nem de materialismo nem de idealismo. O espírito é uma construção, mais do que um sujeito; um complexo processo de incorporação e estilização de experiências e vivências. E, foi como auto-experimentação, que o filósofo veio a compreender que um espírito, como superfície, poderia ser profundo, como aparência, poderia ser criador, como devir, poderia afirmar um caráter. Se a humanidade ocidental é decadência, e se a vida não tem solução e, no cômputo geral dos jogos de forças, não pode melhorar, posto que é trágica, cabe aos espíritos mais seletos a tarefa de realizar-se como pletora de forças, ou seja, fazer-se criadores, espiritualizar-se.

\section{O pensamento abismal}

Podemos expressar o anseio nietzschiano da transvaloração de uma maneira que se articulem vida e pensamento. Preliminarmente, é preciso 
afirmar o seguinte: se Nietzsche escreveu que a obra (ou a criação) lhe era mais cara que a própria felicidade, e se, para ele, o pensamento deveria ser expressão de vida, qualquer referência ao pathos nietzschiano encontra-se apoiada em seus pensamentos como as suas criações mais visíveis e comunicáveis. Os pensamentos, expressos em imagens, afirmações e análises tão singulares, são a porta da frente pela qual se adentra a espiritualidade nietzschiana. Percorrer a vastidão dos pensamentos do filósofo, averiguar as direções a que eles foram conduzidos, chegar aos mares mais profundos e aos abismos mais elevados: eis o único veio possível para a postulação de uma "ética" em Nietzsche. É assim que se entenderá de que forma as reflexões críticas sobre a modernidade projetaram-se como resposta pessoal à decadência e ao niilismo.

Os pensamentos como reflexos de uma espiritualização artística, como consciência que transfigura, em estilo de linguagem, as profundezas e a abundância da alma. No domínio do artístico, uma idéia projetou-se como signo da obra, que o filósofo chamou de o seu "pensamento abismal": a idéia do "eterno retorno". Este "pensamento abismal" sintetiza o posicionamento cosmológico do espírito. O espírito compreende-se não apenas como uma configuração psíquica e cultural de base corpórea, e, muito menos, apenas como humanidade; ele sente-se parte de um "todo" que não pode ser avaliado, o que torna a existência uma condição incomensuravelmente irresponsável: "a fatalidade de seu ser não pode ser destrinchada da fatalidade de tudo o que foi e será" (Nietzsche, 2006, p.46). Nietzsche aspirou a tomar a vida, com sua pletora de acontecimentos casuais, como uma providência pessoal; a fatalidade como predestinação (Nietzsche, 2000, §277). E a grande predestinação é o eterno acontecer e retornar de todas as coisas. Ele exprimiu isso também pela noção de "sentido da terra" ou predestinação terrena para a vida.

A idéia do eterno retorno é bastante enigmática. Afora os descuidos nietzschianos com a melhor sistematização das suas noções, a dificuldade de compreendê-la provém de ser um pensamento mais de ordem do vivido do que do pensado. E ela é dita "abismal" pelo quanto incomoda. Trata-se de um sentimento da fatalidade de todas as coisas a ponto de se desejar o seu retorno eterno, o que supõe a abertura para a experimentação intensa e profunda do vivido. O eterno retorno não é uma ciência, no sentido de que não pode ser avaliado tecnicamente, nem é uma mística, no sentido de que não se trata do convite para experimentá-lo como possessão. Trata-se de uma filosofia de vida, um pensamento-afeto ou um pensamento-valor. Por isso, equivocam-se aqueles que, como Unamuno (s/d, p.85) e Borges (1993, p.59-67), vêem no pensamento do eterno retorno apenas uma teoria física da combinação das forças, com o que tentam descaracterizá-la como uma "tragicomédia" de matematização da questão da imortalidade ou refutá-la 
como logicamente "patética". O que Nietzsche quis estabelecer com a "hipótese" da repetição do jogo das forças no tempo eterno não foi tanto uma prova científica - afinal, impossível (Machado, 1997, p.151) - quanto a afirmação incondicional do vivido a ponto de se desejar o seu retorno. O pensamento do eterno retorno é a estilização maior de um pathos afirmativo, a transfiguração máxima de um sim à vida. Sob essa ótica, é muito mais ético do que teórico. Mesmo que, por vezes, teoricamente justificada, a hipótese do eterno retorno não se direcionava tanto ao debate científico, com o que se procura refutar essa ou aquela teoria, mas sim ao projeto imoralista, quando o filósofo julga ter encontrado a idéia com a qual destronava o idealismo moralizante do mundo, com o intuito de valoração da vida como acontecimento e devir. O aspecto mais polêmico da teoria - a pressuposição da finitude no número de combinações de forças - é uma contraposição valorativa ao idealismo com sua postulação de um outro mundo e de que as coisas poderiam ou podem ser diferentes.

Há também a interpretação de Deleuze, igualmente criticada por Rosset (2000, p.87-88) e Ansell-Pearson (1997, p.128), do eterno retorno como uma seleção das forças ativas e uma negação das forças reativas, que não devem retornar. Nesse caso, Deleuze corre o sério risco de cair na fórmula "faça apenas o que merece ser repetido eternamente", o que condenaria o pensamento a uma espécie de "imperativo ético" ou a uma autonomia do sujeito, estranhos a um pensador que repudiou o "não" ou o "nunca mais" à vida, mesmo que dirigido às forças reativas (Ansell-Pearson, 1997, p.128), bem como realçou o fatalismo. Já Rosset, ele nos lembra do "demônio" que desafia a aceitar tudo que é grande e pequeno.

Faça-se um jogo com essas interpretações. Por um lado, a distinção acima entre um traço teórico e um traço afetivo na doutrina do eterno retorno permite contemplar as duas interpretações, ao invés de colocar uma contra a outra, como fazem alguns críticos. Como idéia, a doutrina revela a validação incondicional de toda existência, incluindo as forças reativas e a pequenez humana; como afeto, seu traço decisivo, ela é seletiva e anula as forças reativas. Ou seja, enquanto referido à disposição psicológica do espírito diante da existência, como figuração do "sim", ou seja, como pensamento-afeto - e tão-somente nesse sentido - o eterno retorno é puramente expressão de forças afirmativas. E como é este o sentido dominante, Deleuze não deixa de ter razão. Por outro lado, porém, sendo a distinção dos aspectos filosófico e psicológico da doutrina tão-somente esquemática, o "pensamento abismal", enquanto expressão do espírito que se enlaça à vida como eternidade, é um ato ativo que tem como significado a aceitação incondicional da grande "amada", com todas as suas fraquezas e contradições. Mas tal aceitação é essencialmente ativa. Portanto, no que há de decisivo na idéia do eterno retorno - sua integridade como pensamento-afeto 
mais expressivo do ideal de transvaloração - ou seja, sua conotação ética o eterno retorno é um pensar ativo. Por fim, o que faltou a Deleuze foi articular devidamente o "valor" e o "sentido" na idéia do retorno: para Nietzsche-Zaratustra, a aceitação do "significado" da idéia como o retorno de tudo, inclusive do pequeno, do reativo e do doentio, é o que há de mais valoroso e mais afirmativo no pensamento do eterno retorno. O fato de o "último homem" não "suportar a prova" do eterno retorno não indica que ele não retornará, como quer Deleuze (2006, p.410), mas confirma que a afirmação tem um sentido psicológico.

\section{II}

O sentido ético do eterno retorno é a afirmação incondicional do momento como o signo do necessário. Com o término de toda idéia de progresso e do "Deus ex-machine", só o momento, inapreensível na sua riqueza, pode retornar, porque só ele representa a idéia do vivido. E não se trata tanto da certeza do retorno ou, muito menos ainda, de experimentá-lo plenamente, pois, isso é impossível, uma vez que o espírito, por conta da sua condição perspectivista, está condenado a nunca viver a plenitude do retorno; tratase, sim, de afirmar incondicionalmente o momento como se o desafiasse ao retorno. Portanto, não se trata de uma solução simbólica ou ideativa, forjada na consciência. No essencial, a idéia do retorno eterno sela a desconstrução do "eu" pelo fluxo incessante dos instantes, a exigir novas disposições, reconduzindo "a intenção à intensidade" (Klossowski, 2000, p.134).

Há uma ressignificação da idéia de eternidade, que perde a sua aura divina, embora conserve um traço místico ou, mais corretamente, o traço de um enigma. A eternidade é sempre presença, não como simples estar temporal no mundo, mas como um estar, um esteve e um estará: "Ó minha alma, ensinei-te a dizer 'Hoje', como 'Algum dia' e 'Outrora' e a dançar a tua ciranda para além de todo aqui e ali e acolá" (Nietzsche, 1994, p.232). A "ciranda" [Reigen] é o símbolo do tempo como momento e, não, como movimento, pois, no círculo, como tudo retorna, anula-se o sentido do próprio deslocar. O deslocamento é, sim, uma categoria espacial - o aqui, ali e acolá - e o tempo, para Nietzsche, não pertence ao espaço. Quando ele representa o tempo como deslocamento é tão-somente de forma figurada e para um sentido da afirmação incondicional da vontade diante das sensações de passado, presente e futuro, contra o espírito da vingança que não aceita o acontecido. E o "meio dia" é a síntese do círculo e do eterno, a melhor representação do "momento".

Acima de tudo, transmutando o tempo em eternidade e desejando o retorno desta, Nietzsche quis afirmar o "efetivo", pois, como interpretou 
Heidegger, "a mais profunda recalcitrância contra o tempo, porém, não consiste na mera subestimação do que é terreno. Para Nietzsche, a vingança mais profunda consiste naquela reflexão que coloca os ideais supraterrenos como absolutos, confrontado com os quais o temporal precisa subestimar-se como não-ente, não real" (Heidegger, 1997, p.101). E, se Nietzsche insiste na idéia do retorno, não o faz como recusa do transitório e algum desejo de perpetuação e imortalidade, mas essencialmente como acolhimento do vivido.

O pensamento do eterno retorno está claramente ligado ao traço cosmológico da visão nietzschiana da vida como complexo de forças em ação (Nietzsche, 1983, p.397). E a cosmologia tem expressividade tanto teórica quanto existencial. A primeira aparece na interpretação da vida como um universo de forças e tem um sentido "hipotético"; a segunda aparece na estilização da vida como um pathos trágico de forças e tem um sentido "artístico". No primeiro, trata-se de ficção teórica, no segundo, trata-se da vivência. Por não ser puro pensamento, a cosmologia não indica uma teoria ou uma metodologia; por não ser puro sentimento, não indica uma doutrina mística. Nietzsche era suficientemente místico para ser científico, e era demasiadamente artístico e terreno para ser místico; para além do agradecer (místico) à vida, ele quis dizer-lhe um "sim" (artístico). Todavia, deve-se lembrar que, nele, as ordens do pensamento e do sentimento se confundem. O traço cosmológico do seu pensamento indica, então, uma "sabedoria trágica". O entendimento cosmológico fala do filosófico, o sentimento cosmológico fala do artístico; o saber trágico expressa a disposição do filósofo em interpenetrar essas duas grandes facetas da sua alma.

É na sabedoria trágica que vai vicejar o pensamento do eterno retorno, como o seu fruto mais maduro. E o fruto traz a marca da sua origem, da sua relação umbilical com uma visão cosmológica da existência. Essa visão converge para a compreensão de que tudo na vida é força e que força é vontade de poder. Por isso, estava certo Heidegger ao interpretar o ensinamento de Zaratustra como consistindo na afirmação da vontade de potência como fundamento do real nietzschiano e que é ela própria "que se quer a si mesma no eterno retorno do igual" (Heidegger, 1997, p.89). Acompanhando a divisão na cosmologia, tem-se o duplo registro do "pensamento abismal", o reflexivo e o experiencial. Nietzsche comunica o eterno retorno (e a cosmologia das forças) como idéias, mas confere a estas uma potência de atitude ou de estilo. Se o pathos nietzschiano é marcado pela vivificação do pensamento enquanto formas de espiritualidade instituídas como "afetos de comando" - ao que corresponde a idéia de "incorporação" - o eterno retorno, como "pensamento abismal", é o maior distintivo do pensamento-ato ou do pensamento-afeto. 


\section{III}

As considerações nietzschianas sobre os valores visaram a legitimar uma moral da imoralidade. Ele não abandonou por completo os limites de uma consciência moral e de um dever, embora, ao mesmo tempo, tenha sido o maior adversário das filosofias e religiões do "dever ser", daqueles que se mantêm na fase de "camelo". É que há entre o "dever" nietzschiano e o "dever ser" tradicional uma diferença fundamental. O "dever ser" reflete um espírito escravizado em valores superiores, em alteridades e ilusões; o "dever" faz alusão à pretensão do espírito dedicar-se solitariamente à sua "obra", acima da própria "felicidade" (Nietzsche, 1994, p.12). E qual a grande obra do espírito: "O que diz sua consciência? - "Torne-se aquilo que você é'” (Nietzsche, 2000, §270). O "dever" como produto moral mais elevado de um caráter absolutamente singular.

O "dever ser" é a insígnia da moral tradicional e do espírito alheio de si, na forma de um estado idealizado; o chamado ao "torna-te o que és" é a insígnia da moral nietzschiana, do espírito que toma posse de si como acontecimento e efetividade. No plano da moral, o que separa Nietzsche de Kant não é a recusa da idéia de dever, mas a sua reinterpretação em um conteúdo absolutamente anti-humanista e antiuniversalista. Em Kant, o que ordena a consciência moral? "Faça tudo com base na sua vontade própria, de modo que essa vontade possa ter como objeto a si mesma como uma vontade legisladora universal". Leia-se: só é digno da sua pessoa aquilo que é universalizável e digno de toda humanidade. Ambas as perspectivas centram-se na potência da vontade. Adorno e Horkheimer já apontaram a afinidade entre a vontade nietzschiana com o imperativo categórico kantiano como formas de "despotismo" da vontade (Adorno \& Horkheimer, 1985, p.108). Mas há uma distinção básica, que separa as duas moralidades. Kant condena o espírito e sua vontade ao universo genérico do humano como base da sua liberdade e pessoalidade; em Nietzsche, a proposição é precisamente oposta, pois a afirmação de si é um ato explicitamente egoísta, em que não se busca o universal humano, mas, sim, o particular cósmico.

O que há de mais "abismal" do que afirmar-se como um jogo de potências sobre-humanas com um sentido de eterna criação e destruição de todas as coisas sem um propósito final - e, mesmo assim, sentir-se livre e bem disposto para a vida? Por não pertencer à ordem do "dever ser" é que a doutrina do eterno retorno não prescreve algo do tipo: "fazer apenas o que merece ser repetido eternamente", pois isso implicaria em uma ética restritiva da liberdade maior que experimenta o espírito que vê o mundo como indefinido e aberto às combinações. O imoralista ousa saber que se "Nada é verdadeiro, tudo é permitido". Trata-se da liberdade de se sentir parte da fatalidade do "todo possível", e não da liberdade moral da ação responsável. Se 
assim fosse, mais se assemelharia ao kantiano "fazer apenas o que merece ser válido como lei universal".

A concepção de Nietzsche do eterno retorno, não sendo da ordem de um dever ser, não implica em constrições à ação. É um pensamento de forte ascendência instintiva, um ponto de chegada do andarilho, o seu momento do "meio-dia", espantosamente primitivo e elevado, simples e trágico. Para Nietzsche, não era de um guia ético das suas ações, que lhe ensinasse por onde devia ou não caminhar. O andarilho descobre nele um sentido com o qual pode caminhar e descobre também que não há "o" caminho, mas o devir. Como doutrina, não é um pensamento-lugar, uma moral, mas um pensamento-afeto que revigora a disposição para o caminhar. O fato de Nietzsche associar a sua aparição às caminhadas pelas montanhas e lagos da Suíça alemã faz dele um signo do caminhar.

Em Zaratustra, encontramos o seguinte ensinamento: "Esta é a minha doutrina: quem quiser um dia aprender a voar, deve primeiro aprender a levantar e caminhar e correr e saltar e dançar" (1994, p.203). Caminhar e dançar para se elevar. Nietzsche encontrou no eterno retorno o grande guia para a elevação e superação do espírito. Isso só pode ser entendido se se integram à doutrina do eterno retorno o sentimento do amor fati e a alegria que o acompanha. O melhor lema que a idéia do eterno retorno proclama é: "viver de tal modo que tenhas de desejar viver outra vez" (Nietzsche, 1983, p.390). Vê-se mais claramente o que o pensamento-afeto do eterno retorno instrui, sim: um desejo, uma vontade, uma leveza, um prazer de se viver intensamente cada instante, sentindo no acontecer um traço característico do que se é (idem, pp.383-4). A ética nietzschiana desvelada como o "pathos afirmativo".

Se, como diz Heidegger, o pensamento do eterno retorno permanece como "visão e enigma", avesso a provas e refutações, quer lógicas, quer empíricas (Heidegger, 1997, p.104), o enigma apresenta-se como resposta afirmativa e desafio, e não como "pergunta". Filho dileto de uma sabedoria trágica, o "pensamento abismal" é a própria comprovação da ética nietzschiana como um pathos, conferindo-se ao termo um sentido preciso de saúde e disposição. "Pathos afirmativo": a boa disposição do espírito para a vida. O eterno retorno instrui amor fati (amor ao necessário), não como algo que lhe é logicamente derivado e, sim, como condição psicológica da sua afirmação. Conjugado à máxima do amor fati, o eterno retorno confirma-se como pensamento-afeto. $\mathrm{O}$ amor fati é que distingue a excelência do sentido "ético" da doutrina sobre o sentido "científico", pois como afirma Salaquarda, em alusão à contenda de Zaratustra com o "anão da gravidade": "O arquiinimigo de Zaratustra conhece e afirma o pensamento do círculo, mas não ama a vida." (idem, p.28) O saber nietzschiano almejava ir além do desencanto cético. 


\section{Os sentidos da extemporaneidade: singularidade, solidão, loucura}

\section{I}

O amor fati e o "torna-te o que és": acima de tudo, "ama-te como és", seja capaz de sentir-se distinto - algo bem próximo ao que diz Gide, um escritor que apreciava Nietzsche, em sua autobiografia: "Eu escondia no fundo do coração o segredo do meu destino" (Gide, 1982, p.96). O "torna-te o que és" é, antes de tudo, um mote de "distinção"; é o correspondente positivo do: "Não sigas por onde vai um outro". O espírito que assim se singulariza - tendo o amor fati como o seu grande e silencioso comando afetivo - é aquele que quer jogar com as cartas que a vida lhe ofertou, sempre. Por isso, em uma justiça de caráter nobre não se vê uma preocupação com o significado ou os prejuízos que o erro traz para o "outro" - o escravo, a mulher, o bárbaro, o povo, o mediano, o vulgar - mas, exclusivamente, o significado ou os prejuízos para os "senhores"; a justiça dos senhores não pune com intenção de corrigir, mas simplesmente para punir, por prazer e para afirmação da autoridade. A autoridade nobre não pode ser, tão-pouco, função de uma lei maior impessoal, como acontece com as autoridades modernas. "O egoísmo pertence à essência da alma nobre, quero dizer, aquela crença inamovível de que, a um ser 'tal como nós', outros seres têm de sujeitar-se por natureza, e a ele sacrificar-se"; e essa é precisamente a "justiça" nobre (Nietzsche, 1988, §265). Nietzsche transpôs essa visão da nobreza social e cultural para o afazer do espírito, o espírito que se encontra em transvaloração, o espírito que quer criar novos valores, o espírito do pensar ativo. Para tanto, era preciso a coragem do imoralismo.

Somente é possível a adoção de uma perspectiva extramoral tendo-se aprofundado e mergulhado na baixeza do moralismo humano, ou seja, tendo o espírito experimentado a história, a cultura, o próprio homem. Por isso o filósofo fala em termos de uma auto-superação da moral ou de um conhecimento que desça até as profundezas do que há de mais mascarado no homem, dos seus adornos mais divinos (Nietzsche, 1988, §26); foi isso que ele quis dizer ao referir-se à superação da náusea da sobremesa [Nachtisch Ekel] depois de se "servir" da cultura moral humana (Nietzsche, 1988, §282). É certo que não é necessário ser César para "compreender" César - como dita a perspetiva do puro entendimento - , mas certamente seria preciso experimentar o cesarismo para "superá-lo". Está, novamente, aqui posta a distinção entre o conhecimento como reflexão e o conhecimento como ato.

Nietzsche sentiu-se perigosamente afetado pelas resultantes psíquicas mais decisivas de um longo processo de depreciação histórica das valora- 
ções nobres, característico do Ocidente. Propôs-se, então, a realizar "um ato" digno da tradição perdida. Não com o intuito de uma repetição ou recuperação do passado. A transvaloração a que se propôs não é mera reversão da inversão, com o que ele teria, afinal, permanecido escravo da metafísica como crença na oposição de valores (Nietzsche, 1988, §2). E, se Nietzsche assim quisesse, ele estaria, no máximo, propondo simplesmente o retorno às valorações nobres. Não se trata disso, porque não é possível redimir o passado - daí a necessidade de transformar todo "foi" em um "assim eu quis"; mas também porque é preciso criar novos valores (Nietzsche, 1994, p.145). A transvaloração é a formação de um pathos interpretativo de forças, no qual é a "criação" de novas perspectivas que dá a tônica da afirmação incondicional da vida.

Entre o passado nobre e o presente nietzschiano há uma barreira intransponível, com a qual se potencializavam novos destinos: trata-se da experiência do niilismo. A transvaloração é uma resposta ao niilismo como decadência, uma demonstração de poder de reação, portanto, de saúde. Os nobres fundaram uma moral superior alicerçada em uma crença na boa "origem" e distinção social das suas ações; os escravos inverteram a moral nobre, deslocando o juízo da ação da origem para as "intenções"; Nietzsche desejou para si uma perspectiva "extramoral", daqueles que sabem que o mais valioso nas ações é o "não-intencional", o que passa à margem da leitura consciente e dos idealismos (Nietzsche, 1988, §32). O efeito perverso da responsabilização moral dos homens por suas ações é uma inevitável cisão entre o que se é ou se vivencia e o que se anseia e se idealiza. Uma alma moralizada projeta-se em uma idealização de si, cindindo-se internamente. Daí Nietzsche intitular um dos seus aforismos de "a moral como autodivisão do homem", "na moral o homem não trata a si mesmo como individuum, mas como dividuum" (Nietzsche, 2000a, §57). Uma cisão que se aprofunda quando a moral deixa de ser associada aos complexos ativos de forças - o temo da "moralidade dos costumes" e da "dívida" - para se tornar manifestação de um sentido reativo na configuração das forças - o tempo das "idealizações" e da "culpa". Quando do domínio dos valores nobres, a moral não indicava "idealizações", mas afirmação direta dos impulsos vitais, aos moldes da virtú homérica ou maquiavélica; o herói ou o príncipe integralizavam-se como potências guerreiras.

Na essência da superação da moral está precisamente a percepção de que o que é intencional e consciente é tão-somente a superfície da ação, porque o que de fato decide são forças não intencionais e inconscientes, e nisso consiste a excelência das almas extramorais ou imorais, as quais, embora partícipes do longo período de moralização da vida, conseguem superá-lo afirmando a "irresponsabilidade" diante da humanidade e do seu tempo: "O homem de tal Além, que quer ele próprio avistar as supremas 
medidas de valor do seu tempo, necessita antes 'superar' em si próprio esse tempo" (Nietzsche, 2000, §380). Os nobres estavam "aquém" do bem e do mal; os escravos estiveram sob plena "vigência" do bem e do mal; Nietzsche quis colocar-se "além do bem e do mal". Entre ele e os nobres do passado, há todo um processo historicamente situado e suas conseqüências psíquicas. A crença na origem não pode mais ser recuperada depois que se experimentou o desencanto com as tentativas de se conferir um sentido para a vida.

\section{II}

Apesar da distinção face à perspectiva moral dos antigos senhores, Nietzsche sempre se espelhou nas imagens dos nobres e dos homens dos grandes feitos para identificação do seu espírito, com eles, assim, se irmanando. Isso porque, embora não se tratasse de um retorno às valorações senhoriais, a transvaloração é essencialmente um ato nobre no sentido de que é operada por um espírito que tem reverência por si mesmo e que encontra "felicidade" [Glück] na ação, ao invés de procurá-la, como o escravo, na passividade ou na dor que entorpece (Nietzsche, 1988, §287; 1988a, I, §10). Nietzsche se espelhou nas almas e tempos que reputava superiores pelo que nelas é expressão do mais sublime e corajoso egoísmo. Uma alma nobre alimenta por si mesma uma certeza fundamental de poder e distinção, uma sensação íntima de ser ela um presente do acaso; é essa "fé" [Glaube] em si própria que a singulariza, a qual imprime em suas ações. É por essa fé que se estabelecem as hierarquias. Não se trata, pois, de uma fantasia ou mera imaginação: a fé é apenas uma sensação mais íntima de abundância e potência. Mais do que um sentimento moral, o egoísmo é, para Nietzsche, um sentimento corporal, ou, mais precisamente, o modo de ser afetivamente comandado. Quando Nietzsche desdenha da idéia de ações não-egoístas, ele está pensando cosmologicamente na vida como fluição de forças em busca das suas conseqüências.

Mas, o que há realmente de singular na vivência nietzschiana em relação à vivência nobre tradicional? A grande singularidade é a experimentação de uma nova "necessidade", ligada à superação da moralidade escrava: a necessidade de "libertação para criação". Ele "a" caracterizou como a tarefa de um imoralista, de quem tem que superar o idealismo como a sua "insensatez" (Nietzsche, 1995, p.40). e o niilismo como a sua covardia. As convicções são a morada encantada do "outro", onde o espírito livre não se reconhece como criador, onde é, afinal, passivo, niilista. A mensagem nietzschiana de ir "além do bem e do mal" soa como um além do "outro", o qual está na base da metafísica (crença na oposição de valores) e do comportamento reativo. O outro como sintoma do alheamento de si, cultivado em 
toda moralidade altruísta e germe de todo ressentimento. Há um verso em um dos poemas de Fernando Pessoa de tom nietzschiano quando o poeta diz que "todo mal do mundo advém de nos incomodarmos uns com os outros".

Os nobres de outrora não conheceram a moral das boas e más intenções, por isso não precisaram se curar delas. Nietzsche tinha uma nova necessidade porque era ameaçado por uma doença do "seu tempo" e pelas tentações da sua própria biografia. Mas, novamente, em consonância com o caráter nobre, a condição fundamental por ele concebida para a cura e o exercício da saúde é a "pathos de distância". Trata-se de uma perspectiva tipicamente aristocrática, pois remete a "uma sociedade que acredita numa longa escala de hierarquias e diferenças de valor entre um e outro homem, e que necessita da escravidão em algum sentido" (Nietzsche, 1988, §257); o problema do governo da maioria é a "proximidade" (Nietzsche, 2000, §376). A distância (distinção) e a hierarquia (domínio) são os atributos elementares do socius nietzschiano. E a distância que um nobre naturalmente tende a estabelecer com os seus inferiores visa a um fim ainda mais elevado, um outro pathos: "o desejo de sempre aumentar a distância no interior da própria alma, a elaboração de estados sempre mais elevados, mais raros... em suma, a elevação do tipo 'homem', a contínua auto-superação do homem'" (Nietzsche, 1988, §257). O ensinamento de Zaratustra de que o homem é algo que deve ser superado - o próprio sentido da idéia de Übermensch (Nietzsche, 1994, p.12) - seria dispensável para os ouvidos dos velhos aristocratas. Mas, como não se trata do retorno a uma natureza primitiva em que se enraizaram as sociedades aristocráticas, transvaloração será a denominação que Nietzsche dará ao seu desejo de "auto-superação do homem". A transvaloração é a inscrição "histórica", ou mais precisamente, "temporal", do processo de auto-superação na alma nietzschiana, e, portanto, o modo como nele se revelará uma estirpe nobre.

A possibilidade de se superar a moral está associada a um processo de aprofundamento do homem, que se dirige para a própria negação da centralidade do homem e sua consciência em direção à afirmação das forças naturais, vitais e inconscientes. Como um ato nobre - uma autêntica criação de valores, ao invés da mera inversão reativa característica das estirpes fracas - a superação é uma reaproximação com a cultura dos nobres no que estes sempre demonstraram de apego aos instintos e à vida como perigo. Não é um retorno, porque, para Nietzsche, a superação da moral situa-se em um novo "tempo": o tempo dos espíritos superiores que, por experimentarem as conseqüências mais nefastas da moralização do mundo - o niilismo - podem empreender a transvaloração de todos os valores. É um ato nobre, de quem é "senhor" do seu estilo; e os fracos nunca serão bons psicólogos de si mesmos. Através de novos valores, edificar uma nova subjetividade, é isso que indica o mito poético do Übermensch. 
O Übermensch tem sido um dos motivos de controvérsias entre os intérpretes da obra nietzschiana, uma idéia aberta e disponível ao conflito das interpretações. Pelo enredo interpretativo aqui adotado, ele deve ser entendido menos como um tipo, em relação ao qual poder-se-ia buscar referências histórias ou fazer projeções futuras, e mais como um pathos no qual se diluem todas as valorações superiores (felicidade, razão, justiça, virtude, compaixão): "Em verdade, um rio imundo é o homem. É preciso ser um mar para poder absorver, sem sujar, um rio imundo. Vejam, eu vos ensino o Übermensch: ele é esse mar onde nosso grande desprezo pode submergir" (Nietzsche, 1994, p.11). O Übermensch é o "sentido da terra", que é o sentido nietzschiano de vida, que tem o sentido de superação. E o que deve ser superado? O homem com sua historicidade contaminada de moralidade.

Para além de Kant, talvez Nietzsche se julgasse realizador da verdadeira "revolução copernicana" no âmbito da filosofia, não só por associar o pensamento à vida, mas principalmente ao desejar que o espírito se orientasse por uma pathos, alheio ao bom senso e às razões humanas. Afirmar incondicionalmente a vida, com toda a maldade, incertezas, experimentações e perigos que lhe são inerentes, é a condição nietzschiana para a criação de novos valores. E o grande valor é a criação de si mesmo, da sua "segunda natureza", como espírito que se arrisca na dedicação à sua obra, sua arte, sua vida. Como acentua Safranski, a vontade de poder significa, antes de tudo: conseguir poder sobre si mesmo (Nietzsche, 2001, p.169). Para tanto, é preciso, pois, ir mesmo além dos "outros", dos "ideais", do "tempo", da "humanidade".

A "revolução copernicana", nas mãos de um imoralista, quer-se distinta do sentido científico original, o qual significou a depreciação "objetiva" do homem e um sintoma de passividade (1988a, III, §25). O anti-humanismo de Nietzsche deve ser entendido face ao humanismo metafísico que prevaleceu na cultura ocidental. Pois o projeto de elevação espiritual talvez nos permitisse apresentar o filósofo como o último dos humanistas. O seu mote do "além do homem" e o seu compromisso com a qualidade espiritual dos atos indica a fundação de uma nova subjetividade, um novo espírito, uma nova humanidade no indivíduo (Nietzsche, 1994, p.60).

\section{III}

Todo processo de auto-superação implica no pressuposto essencial da "solidão" como condição para o seu exercício. Quem já leu bastante Nietzsche sabe que são muitas as referências ao tema da solidão como caminho de cura e saúde: "Minha humanidade não consiste em sentir com o homem como ele é, mas em suportar que o sinta... Minha humanidade é uma contí- 
nua superação de mim mesmo. - Mas tenho necessidade de solidão, quer dizer, recuperação, retorno a mim, respiração de ar livre, leve, alegre...Todo o meu Zaratustra é um ditirambo à solidão, ou, se fui compreendido, à pureza..." (Nietzsche, 1995, p.33). Solidão é sinônimo de elevação e ar puro. E a elevação do espírito acima do "humano", do "outro", era a "grande obra" nietzschiana.

Transfigurado na imagem de um Zaratustra que acabou por preferir a solidão aos discípulos, Nietzsche revelou as suas reservas aos que querem ser profetas, mestres ou santos. Também é conhecida a passagem em que afirma preferir ser um sátiro a ser um santo (Nietzsche, 1995, p.17). Com isso deve-se entender uma posição radical do filósofo que não quis criar laços definitivos, com pessoas, relações ou atitudes do tempo que compartilha com seus contemporâneos. Essa é a principal sabedoria de um espírito que se compreendeu tardio e que percebeu que a maior integridade está em ser passagem de novas forças, novas oposições e novos valores. Mas o espírito tardio não está completamente desligado do tempo histórico. O processo de explicitação da extemporaneidade e de construção do "seu" tempo - como o seu "andamento" - porquanto se faz através de uma superação pessoal dos valores e dos sentimentos modernos, denuncia os mais profundos sintomas de um tipo decadente. A presença de um tardio como um princípio de antecipação. A viagem particular que Nietzsche faz pelos "porões" da decadência - a qual ele julgava necessária tanto quanto perigosa, porque era inevitável "passar pela história" e sua "doença" - levou-o a reconhecer acontecimentos e tendências que ainda não teriam sido experimentadas por nenhuma outra alma.

Parece evidente, na personalidade de Nietzsche, o quanto ele se julgava singular e exemplar. Mas, por certo, ele não foi tão expressivo quanto Sócrates e Jesus, pois não foi seguido diretamente por discípulos - o que fez, e talvez compensou de forma literária, pela máscara de Zaratustra. As poucas companhias que gozou foi a de amigos, nem sempre tão apegados a ele. Diante disso, apegou-se ao futuro como o "tempo" em que seria admirado: "nasci póstumo". A diferença em relação a Sócrates e Cristo se deve basicamente ao seu modo de comunicação - o texto, ao invés da fala - e ao seu estilo de vida - o isolamento e o aristocratismo, ao invés do diálogo com os pares ou a comunhão com o povo.

Como Cristo, Sócrates também teve a sua "missão" anunciada; em um caso, por um Anjo, no outro, por um Oráculo. Nietzsche declinou-se de ter uma missão - embora, como se disse, no íntimo acreditasse em si ou um predestinado ou, melhor ainda, como um mestre do futuro, daí também poder usar a máscara do profeta Zaratustra. De qualquer modo, ele não entendeu a sua obra como um serviço ao mundo ou aos homens ou às consciências do seu tempo. Comparativamente poder-se-ia assim situar as três 
figuras: Jesus Cristo, como "enviado", quis ser o mais "santo" dos homens, pelo reconhecimento dos pecados e tentações e pela busca da salvação; Sócrates, como "cidadão", quis ser o mais "sábio" dos homens, pelo reconhecimento das ignorâncias e pela busca do autoconhecimento; Nietzsche, como "solitário", quis ser o mais "imoral" dos homens, pelo reconhecimento das fraquezas e pela busca da criação solitária.

Nietzsche acreditava que o espírito podia ultrapassar as coisas. Não a "coisa-em-si" [Ding an sich], que não existe, mas o que ele experimenta como assimilador seletivo de vivências. Por isso, distinguiu - em si mesmo, antes de tudo - "espiritualidade" e "historicidade", procurando a superação do primeiro elemento no segundo. Era inegável que era partícipe da história e se via seduzido, ao mesmo tempo em que tolhido, pelas convenções morais ou sociais. O "humano" e a "história" aqui entendidos pelo laço moral que liga o espírito ao mundo. Mas Nietzsche percebeu-se como homem solitário, livre e ligado ao devir incessante. A solidão é a crença no artístico acima da profissão social, no querer acima da responsabilidade, na vida acima do mundo, no espírito acima da história. Na solidão diante da historicidade, elevava-se a tarefa imoralista do espírito: tomar o lema da "sua própria história", navegar por mares nunca antes navegados, para fazer brotar em si o sentimento de uma nova "humanidade" e dar a si uma história. Para tanto, requer-se a intrépida solidão dos grandes navegadores, capazes de "sentir o conjunto da história humana como sua própria história"; para tanto, era preciso "esquecer o presente" (Nietzsche, 2000, §337).

Ir além da história coletiva, ser supra-histórico: para onde isso conduz? Para a vida. A vida, essa sereia de quem Zaratustra quis se saciar com a ousadia de um Ulisses desarmado, um Ulisses dionisíaco, embora de modo algum ingênuo. Algumas vezes, por certo, o espírito pensa refugar diante dos encantos da vida, protegendo-se em algum ardil da razão ou da moral. Mas a loucura, para Nietzsche, é o retrato de um Ulisses desarmado, ou, dizendo o mesmo em outro registro, a vida vista como o oceano onde o espírito mergulha para criar a sua obra, para além da felicidade, pois entregarse às forças vitais - o "canto", as "madeixas", a "calda" os "seios", a "beleza" (Nietzsche, 1994, 235-238) - é sofrer. Mas o sofrimento é a condição elementar de toda grande criação.

Quando ele diz, mesmo que metaforicamente, que o homem é algo a ser superado, pois sua "grandeza" consiste em ele "ser ponte, e não meta: o que pode amar-se, no homem, é ser uma transição e um acaso" (Nietzsche, 1994, p.12), é por compreender a liberdade do espírito como um processo de "elevação". E o espírito só se consegue colocar "além do homem" - sua "meta" é o Übermensch - quando é capaz de pôr em risco e perder a sua integridade moral e a sua inserção histórica, com todo o conforto e felicidade que delas se desprendem, "ir às últimas conseqüências" na superação de si 
e do seu tempo. Na jornada imoralista, não se trata, como quererá a crítica racional, de ir às últimas conseqüências do saber consciente, mas, sim, das experiências, da vida, do saber instintivo sobre a sua derradeira natureza. Para tanto, era necessário mesmo um certo sacrifício da "razão", ousando àquilo a que a moral vigente julgava sua maior ameaça: a loucura.

\section{IV}

Nietzsche afirmou que o "maior perigo" que paira sobre a humanidade com sua "racionalidade" e "mente disciplinada" é a "irrupção da loucura [Wahnsinn] - isto é, a irrupção do capricho no sentir, ver e ouvir, o gosto na indisciplina da mente, a alegria no "mau senso'" (Nietzsche, 2000, §76). Então, o seu imoralismo implicava em ousar o que a moral julga ser o maior perigo. Por isso também se refere ao "além do homem" como "a loucura com que deveríeis ser vacinados!" (Nietzsche, 1994, p.12). A loucura é a última grande máscara do homem, um sintoma da ação de forças livres. Para o "espírito livre" a loucura é um meio, uma "vacina" ou "antimoralina" que tonifica o espírito contra a moral, e, não, contra a verdade, ou menos ainda, contra o saber. Tanto é que Nietzsche, quando se refere à loucura como sentido final, ele a desqualifica: "Mas existem dois tipos de sofredores, os que sofrem de abundância de vida (...) e depois os que sofrem de empobrecimento de vida, que buscam silêncio (...) ou a embriaguez, o entorpecimento, a convulsão, a loucura" (Nietzsche, 2000, §370).

A loucura deve ter um "andamento alegre". [fröhliches Tempo] Como tudo o mais - sofrimento, prazer, conhecimento - a loucura não é interessante em si mesma, mas consoante a relação fundamental com a vida. Assim, há a loucura como sinônimo de fuga do mundo, um entorpecer de sensualidade, a loucura como último refúgio; e há a loucura como sinônimo de afirmação incondicional do mundo, que não é alternativa à náusea diante da pequenez humana, mas, sim, meio para superação da náusea. A diferença fundamental entre os dois sentidos é a seguinte: em um caso - a loucura como fim -, revela-se um anarquismo de forças; no outro - a loucura como meio -, revela-se a presença de afetos de comando. Em um caso, a loucura é sintoma doentio, uma espécie de pathos apático; no outro, ela é sinônimo de saúde, um pathos criativo. A loucura estilizada de Nietzsche é a do andarilho que sabe que, para avaliar sem preconceito os preconceitos morais, é necessário "abandonar a cidade"; e, "ir para fora" é ir "para cima" (Nietzsche, 2000, §380).

A loucura de que tão afirmativamente falou - "Só louco! Só poeta!" - é aquela de quem vive a sua "sétima solidão", de quem experimenta os sentidos do corpo e da terra. Só "pode" viver essa loucura o espírito que é "leve" 
o suficiente para ela, que se encontra acima do seu maior inimigo, o "espírito da gravidade" [Geist der Schwere]. "O fato de querermos ir lá fora, para cima, é talvez uma pequena audácia [Tollheit], um insensato e peculiar 'tu deves' (...) a questão é se realmente podemos ir lá para cima" (ibidem). É preciso ser leve o suficiente para que o "andamento alegre" da loucura nos faça dançar e elevar, ao invés de confundir e paralisar a vontade. "É preciso ser muito leve, a fim de levar sua vontade de conhecimento a uma tal distância e como que acima do seu tempo..." (ibidem). Filosoficamente falando, a loucura do perspectivismo: se tudo é permitido, há sempre a possibilidade de visões e vivências outras.

Nietzsche ousou a loucura, não como apatia ou fim demente que veio a ter, mas como último sintoma de sanidade das potências vitais; também, não como alívio ou prazeres momentâneos, mas como abundância e criação. Ironicamente pode-se talvez dizer que a vida lhe pregou uma peça quando lhe trouxe como destino a insanidade do esgotamento mental. Aquele que viu a loucura como sua derradeira razão, como expressão de vitalidade, liberdade e autenticidade, acabou por nela encontrar o encerramento das suas obras e a apatia; aquele que viveu a tragédia de ser um campo de batalha e experimentou sentidos e pensamentos abismais acabou por sucumbir na tragédia da demência mental. Uma versão mais decepcionante desse drama sugere que "Nietzsche, na tensão de um esforço eternamente frustrado, há de contemplar, em ciclos sem fim, as suas aspirações efêmeras de super-homem malograrem nas trevas de uma loucura sem remédio" (Carvalho, 1989, p.126). Todavia, se se considera que a loucura "apática" foi o preço que o filósofo acabou por pagar por ousar a loucura "ativa", serviram, então, as palavras de Rosa Dias: "É esta a tragédia nietzschiana. O delírio como perda de identidade, a loucura como esmaecimento da razão não marcam o desmascaramento de Nietzsche, mas a sua realização suprema" (apud Lins, 2002, p.267). Mas esse talvez seja apenas o consolo dos que amam o filósofo. Acima de amores e ódios, talvez apenas estejamos face à confirmação da insignificância do homem e sua vontade diante do caos e da indiferença da natureza.

NOBRE, R. F. Nietzsche and the stylization of a character. Trans/Form/Ação, (São Paulo), v.29(2), 2006, p.181-202.

- ABSTRACT: This article discusses the notion of stylization of character in the thought of Friedrich Nietzsche through a few central themes of his philosophy, such as the evaluative critique of western modernity, the 'eternal recurrence' and the meaning of 'untimely'. Using his complete works and a few interpreters, the article aims at establishing an interpretation of the meaning of 'active wis- 
dom' through the development and the mixture, simultaneously unsystematic and careful, of the themes mentioned above.

- KEYWORDS: Nietzsche; stylization of character; eternal recurrence; untimeliness; loneliness.

\section{Referências bibliográficas}

ADORNO, Theodor; HORKHEIMER, Max. Dialética do esclarecimento: fragmentos filosóficos. Rio de Janeiro: Jorge Zahar, 1985

ANSELL-PEARSON, Keith. Nietzsche como pensador político: uma introdução. Rio de Janeiro: Jorge Zahar, 1997.

BORGES, Jorge Luis. A doutrina dos ciclos, História da eternidade. 3ed. São Paulo: Globo, p.59-67, 1993.

COSTA, Jurandir. Culpa e dívida em Nietzsche. Revista Extensão. Cadernos da PróReitoria de Extensão da PUC Minas, v.11, n.35-36, ago/dez 2001.

DELEUZE, Gilles. Diferença e repetição. São Paulo: Perspectiva, 2006.

DURANT, Will. Os pensadores: a história da filosofia. São Paulo: Nova Cultural, 1996.

GIDE, André. Se o grão não morre. 2ed. Rio de Janeiro: Nova Fronteira, 1982.

HEIDEGGER, Martin. A questão da técnica: quem é o Zaratustra de Nietzsche, Ensaios e Conferências. Petrópolis: Vozes, 1997, p.11-38, 87-110.

KLOSSOWSKI, Pierre. Nietzsche e o círculo vicioso. Rio de Janeiro: Pazulin, 2000.

KOSSOWITCH, Leon. Signos e poderes em Nietzsche. São Paulo: Ática, 1979.

LINS, Daniel. Nietzsche e Deleuze: o que pode o corpo. Rio de Janeiro: Relume Dumará, 2002.

MACHADO, Roberto. Zaratustra: tragédia nietzschiana. Rio de Janeiro: Jorge Zahar, 1997.

MOURA, Carlos E. de (org.) Escritos sobre a religião dos orixás, São Paulo, Ed. Edicom/Edusp, 1989

NIETZSCHE, Friedrich. Nietzsche: Coleção os pensadores. São Paulo: Abril Cultural, 1983.

Jenseits von Gut und Böse. Stuttgart: Reclam, 1988 (Além do bem e do mal. São Paulo: Cia das Letras, 1996)

Zur Genealogia der Moral. Stuttgart: Reclam, 1988a (Genealogia da Moral. São Paulo: Cia das Letras, 1998)

Also Sprach Zarathustra. Stuttgart: Reclam, 1994 (Assim falou Zaratustra. Rio de Janeiro: Bertrand Brasil, 1998).

Ecce Homo. São Paulo: Cia das Letras, 1995.

Die Fröhliche Wissenschaft. Stuttgart: Reclam, 2000 (A gaia ciência. São Paulo: Cia das Letras, 2001).

Humano, demasiado humano. São Paulo: Cia das Letras, 2000a. 
NIETZSCHE, Friedrich. Crepúsculo dos Ídolos. São Paulo: Cia das Letras, 2006.

SAFRANSKI, Rüdiger. Nietzsche: biografia de uma tragédia. São Paulo: Geração Editorial, 2001.

SIMMEL, George. Schopenhauer y Nietzsche. Buenos Aires: Ediciones Anaconda, 1950.

UNAMUNO, Miguel de. O sentimento trágico da vida. Lisboa: Ed. Relógio D'água, s.d. 